\title{
Development of biofilm in anaerobic reactors treating wastewater from coffee grain processing
}

\author{
Fátima R. L. Fia ${ }^{1}$, Alisson C. Borges ${ }^{1}$, Antonio T. de Matos ${ }^{1}$, Iolanda C. S. Duarte ${ }^{2}$, Ronaldo Fia ${ }^{1}$ \& Lidiane C. de Campos ${ }^{1}$
}

\begin{abstract}
In recent decades the use of anaerobic fixed bed reactors has been established in Brazil for the treatment of different effluents. As the capability of retaining microorganisms by support media (fixed bed) is a factor influencing the performance of these reactors, the present study aims at evaluating the influence of three fixed bed on the effectiveness of treating an effluent with high pollution potential: wastewater from coffee grain processing (WCP), with organic matter concentrations varying from 812 to $5320 \mathrm{mg} \mathrm{L}^{-1}$ in the form of chemical oxygen demand (COD). Support media used for the immobilization of biomass were: blast furnace slag, polyurethane foam and \#2 crushed stone with porosities of 53, 95 and $48 \%$, respectively. The mean efficiency of COD removal in the reactor filled with polyurethane foam was $80 \%$, attributed to its higher porosity index, which also provided greater retention and fixation of biomass which, when quantified as total volatile solids, was found to be $1301 \mathrm{mg} \mathrm{g}^{-1}$ of foam. The biofilm was made up of various microorganisms, including rod, curved rods, cocci, filaments and morphologies similar to Methanosaeta sp. and Methanosarcina sp.
\end{abstract}

Key words: anaerobic treatment, microbial biomass, support media, coffee

\section{Desenvolvimento de biofilme em reatores anaeróbios tratando água residuária do processamento dos frutos do cafeeiro}

\begin{abstract}
RESUMO
Nas últimas décadas tem-se registrado, no Brasil, o uso de reatores anaeróbios de leito fixo para o tratamento de diversos tipos de efluentes. Uma vez que a capacidade de retenção de micro-organismos pelo meio suporte (leito fixo) é fator de influência no desempenho desses reatores, buscou-se, com a realização do presente estudo, avaliar a influência do leito fixo na eficiência de três unidades tratando um efluente com elevado potencial poluidor: água residuária do processamento dos frutos do cafeeiro (ARC), com concentração de matéria orgânica variando entre 812 e $5.320 \mathrm{mg} \mathrm{L}^{-1}$ na forma de DQO. Os tipos de suporte utilizados na imobilização da biomassa foram: escória de alto-forno, espuma de poliuretano e brita $n^{\circ} 2$, com índice de vazios de 53, 95 e 48\%, respectivamente. A eficiência média de remoção de DQO no reator preenchido com espuma de poliuretano foi de $80 \%$, atribuída ao seu maior índice de vazios o qual proporcionou também maior retenção e fixação da biomassa que, quantificada na forma de SVT, foi equivalente a $1.301 \mathrm{mg} \mathrm{g}^{-1}$ de espuma. O biofilme apresentou variedade de microrganismos tendo-se registrado bacilos, bacilos curvos, cocos, filamentos, e morfologias semelhantes a Methanosaeta sp. e Methanosarcina sp..
\end{abstract}

Palavras-chave: tratamento anaeróbio, biomassa microbiana, meio suporte, café

DEA/UFV. Av. PH Rolfs s/n. - Campus da UFV. CEP 36570-000, Viçosa, MG. Telephone: (31) 3899-2729. E-mail: fatima.luiz@ufv.br; borges@ufv.br; atmatos@ufv.br; ronaldo.fia@ufv.br; lidiccampos@hotmail.com

2 UFSCar. Rodovia João Leme dos Santos, Km 110 - SP-264, Bairro do Itinga. CEP 18052-780, Sorocaba, SP. E-mail: iolanda.duarte@gmail.com 


\section{INTRODUCTION}

Fixed bed anaerobic reactors have been successfully employed for the treatment of different types of wastewater owing to their excellent capacity of retaining microorganisms in a support media. Improvements made in the configuration of these reactors resulted in systems far more stable, controllable and with high degradation efficiency, even when operated with reduced hydraulic retention time (HRT); something attributed to elevated biomass concentrations and to greater cellular retention time (Lima et al., 2005).

These reactors do have something in common: a support cover material whose purpose is to retain biomass in the system interior; be them glued to the material surface, in the form of a biofilm, or, otherwise, adhered to the cover's interstitial spaces in the form of bio-particles like flakes or granules. The immobilization of microorganisms results from their adherence to a solid or else suspended, being as it is influenced by cell-to-cell interaction or by environmental composition (von Sperling, 1996), not to mention the main characteristics of the supporting material, such as form, size, porosity, specific surface, solid quality and its electrostatic charges (Ortega et al., 2001).

Crushed stone \#4 is by far the most used material as the ideal filler for the support media of fixed bed reactors; mainly when the treated effluent is the domestic sewage. However, other materials may be used experimentally since crushed stone is highly dense and rather costly in certain regions rendering the installation of reactors very expensive.

Out of a number of support materials commonly used for the adherence and growing of anaerobic biomass there are the following: coconut shells (Torres et al., 2003), porous ceramics (Zellner et al., 1987; Kawasc et al., 1989; Gourari \& Achkari-Begdouri, 1997), nylon fibers (Chaiprasert et al., 2003), PVC rings (Ruiz et al., 1997 and Show \& Tay, 1999).

According to Ortega et al. (2001), the utilization of supports capable of immobilizing the active biomass allows one to increase the mean time of its permanence inside the reactors, which favors the methanogenic population, increasing the capacity of the reactor to resist load shocks, the changes in the substrate features and the presence of inhibiting compounds.

Because biomass immobilization is an import factor in the functioning of these anaerobic systems, the present study proposes an evaluation of the influence of various support materials (blast furnace slag, polyurethane foam and \#2 crushed stone) on the development of biomass retention in fixed bed anaerobic reactors when treating wastewater from the coffee grain processing (WCP).

\section{MATERIAL AND METHODS}

Reactors were constructed in PVC in a cylindrical form $-0.35 \mathrm{~m}$ diameter and $1.5 \mathrm{~m}$ high, with total capacity of $0.1395 \mathrm{~m}^{3}$ (Figure 1). These units consisted of support media, reaching $1.0 \mathrm{~m}$ high, and placed on a false bottom platform which was placed $0.2 \mathrm{~m}$ away from the reactor base.

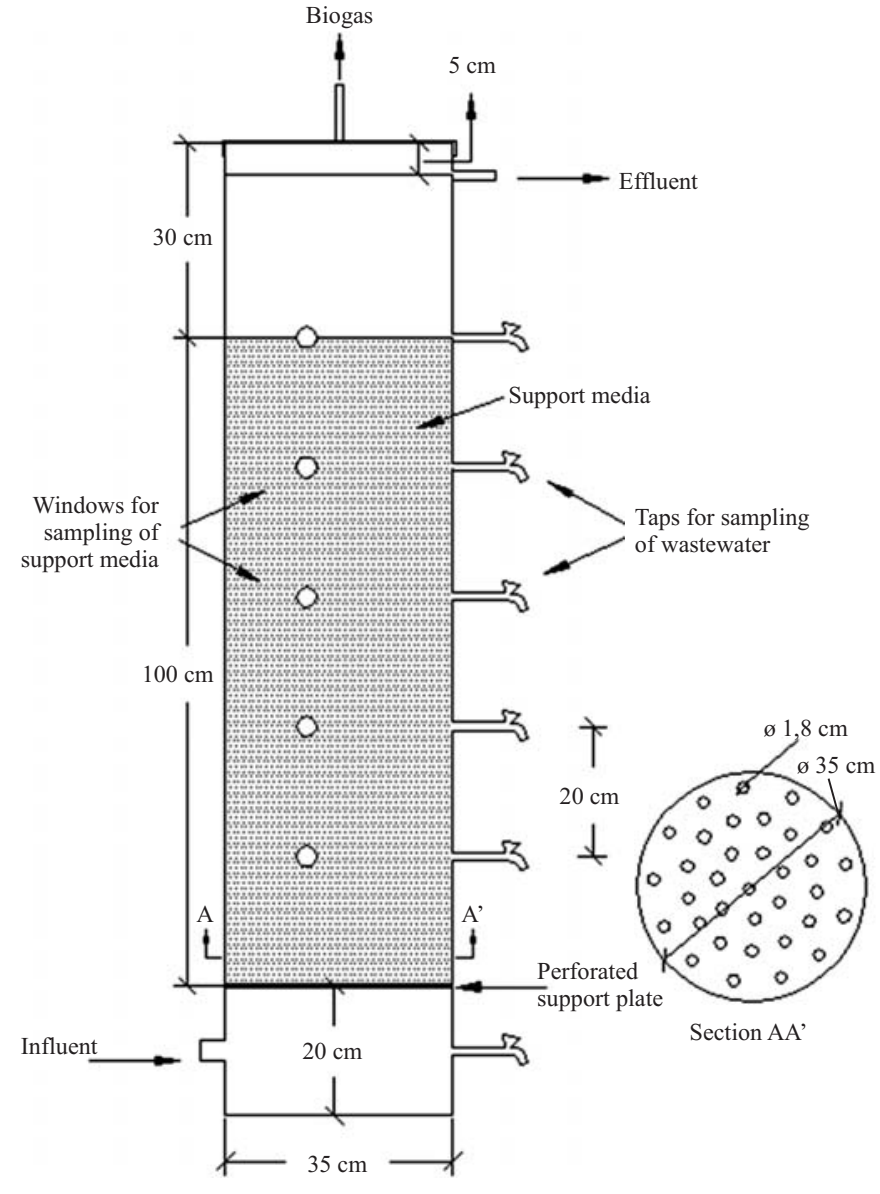

Figure 1. Schematic drawing of a fixed bed anaerobic reactor and the false bottom

The false bottom contained 35 holes of $0.018 \mathrm{~m}$ diameter evenly distributed. Sample collectors for the supporting material were placed on top of and along the reactors in order to quantify and qualify the biofilm obtained.

To obtain support material for the immobilization of biological solids, blast furnace slag, polyurethane foam and granite-gnaisse crushed stone, with porosity of 53, 95 and $48 \%$, respectively, were employed. Crushed stone and blast furnace slag presented varying diameters: from 0.024 to $0.032 \mathrm{~m}$, and the polyurethane foam was cut to an edge of $0.025 \mathrm{~m}$. An analysis of the chemical composition of slag is shown in Table 1.

Table 1. Chemical characterization of the blast furnace slag utilized

\begin{tabular}{|c|c|c|c|c|c|c|c|c|c|c|}
\hline $\mathrm{SiO}_{2}$ & $\mathrm{CaO}$ & $\mathrm{MgO}$ & $\mathrm{Al}_{2} \mathrm{O}_{3}$ & $\mathrm{FeO}$ & $\mathrm{MnO}$ & $\mathrm{K}_{2} \mathrm{O}$ & $\mathrm{Ti}$ & $S$ & $\mathrm{Cr}_{2} \mathrm{O}_{3}$ & Basicity \\
\hline \multicolumn{10}{|c|}{$\left(\right.$ dag $\left.\mathrm{kg}^{-1}\right)$} & index \\
\hline 41.37 & 27.66 & 10.1 & 11.53 & 2.04 & 1.29 & 1.00 & 0.56 & 0.076 & 0.014 & $0.66^{\star}$ \\
\hline
\end{tabular}

\section{Wastewater}

Wastewater from the coffee grain processing used for the experiment was collected at the Unit of Coffee Processing of the UFV.

In view of the lower $\mathrm{pH}$ levels and because of the high concentration of volatile acids presented by the WCP, a complementation of effluent alkalinity to the reactors was con- 
sidered necessary, and for such, solid carbonate was utilized. According to Omil et al. (2003), the added alkalinity is crucial for securing a buffer medium so as to preserve $\mathrm{pH}$ stability. The wastewater characterization employed during the three-phase monitoring system can be seen in Table 2.

Table 2. WCP characterization used during the three-phase monitoring system (mean values and standard deviation)

\begin{tabular}{cccc}
\hline Variables & \multicolumn{3}{c}{ Phase } \\
\cline { 2 - 4 } $\mathrm{pH}$ & $6.44 \pm 0.59^{(31)}$ & $6.55 \pm 0.46^{(22)}$ & $7.06 \pm 0.14^{(21)}$ \\
$\mathrm{EC}$ & $0.66 \pm 0.13^{(29)}$ & $1.78 \pm 0.40^{(21)}$ & $3.78 \pm 0.55^{(21)}$ \\
$\mathrm{COD}$ & $978 \pm 113^{(16)}$ & $2401 \pm 597^{(13)}$ & $4545 \pm 511^{(16)}$ \\
$\mathrm{BOD}_{5}$ & $457 \pm 78^{(5)}$ & $1248 \pm 300^{(4)}$ & $2342 \pm 376^{(5)}$ \\
$\mathrm{BA}$ & $74 \pm 63^{(18)}$ & $199 \pm 165^{(12)}$ & $575 \pm 98^{(16)}$ \\
$\mathrm{TVA}$ & $300 \pm 88^{(18)}$ & $969 \pm 177^{(12)}$ & $2021 \pm 360^{(16)}$ \\
$\mathrm{TS}$ & $664 \pm 162^{(10)}$ & $2317 \pm 605^{(10)}$ & $4755 \pm 1052^{(13)}$ \\
$\mathrm{TVS}$ & $419 \pm 115^{(10)}$ & $1298 \pm 473^{(10)}$ & $2525 \pm 627^{(13)}$ \\
$\mathrm{TSS}$ & $54 \pm 3^{(3)}$ & $124 \pm 56^{(5)}$ & $215 \pm 50^{(8)}$ \\
VSS & $51 \pm 40^{(3)}$ & $116 \pm 51^{(5)}$ & $202 \pm 49^{(8)}$ \\
Phenol & $13.0 \pm 3.8^{(10)}$ & $19.7 \pm 4.2^{(12)}$ & $42.7 \pm 5.3^{(16)}$ \\
$\mathrm{N}_{\mathrm{T}}$ & $13.7 \pm 4.4^{(6)}$ & $29.0 \pm 13.8^{(4)}$ & $71.2 \pm 17.6^{(5)}$ \\
$\mathrm{P}_{\mathrm{T}}$ & $3.7 \pm 2.7^{(6)}$ & $3.2 \pm 0.7^{(4)}$ & $8.0 \pm 2.3^{(5)}$ \\
\hline
\end{tabular}

$\left(^{*}\right)$ The number of samples taken into account for the calculation of the mean is found in parenthesis $\mathrm{EC}$ - electrical conductivity ( $\left.\mathrm{dS} \mathrm{m}^{-1}\right)$; COD - chemical oxygen demand $\left(\mathrm{mg} \mathrm{L}^{-1}\right)$; BOD - biochemical oxygen demand ( $\left.\mathrm{mg} \mathrm{L}^{-1}\right)$; $\mathrm{BA}$ - bicarbonate alkalinity $\left(\mathrm{mg} \mathrm{L}^{-1}\right.$ of $\left.\mathrm{CaCO}_{3}\right)$; TVA - total volatile acids ( $\mathrm{mg} \mathrm{L}^{-1}$ de acetic acid) TS - total solids $\left(\mathrm{mg} \mathrm{L}^{-1}\right)$; TVS - total volatile solids ( $\left.\mathrm{mg} \mathrm{L}^{-1}\right) ; \mathrm{TSS}$ - total suspended solids ( $\left.\mathrm{mg} \mathrm{L}^{-1}\right)$; VSS - volatile suspended solids $\left(\mathrm{mg} \mathrm{L}^{-1}\right) ; \mathrm{N}_{T}-$ total nitrogen ( $\left.\mathrm{mg} \mathrm{L}^{-1}\right)$; $\mathrm{P}_{\mathrm{T}}$ - total phosphorus $\left(\mathrm{mg} \mathrm{L}^{-1}\right)$

\section{Experimental Procedure}

In order to secure the immobilization of biomass on the matrices of the support material, sewage sludge with high concentration of TVS and VSS of 41346 and $36860 \mathrm{mg} \mathrm{L}^{-1}$ was used. By means of a technique described by Zaiat et al. (1994), the support material together with the macerate sludge was stored in $200 \mathrm{~L}$ barrels, and homogenized accordingly for the period of a week so as to secure steadier immobilization of bio-particles in the supporting material. Afterwards, the blast furnace slag, the polyurethane foam and the crushed stone were kept in their own reactors, taking care that compression would not occur during this process, proceeding then with the reactors start up phase, a period during which smaller organic loads were efficiently administered - a phase when the reactor operation is shown to be most delicate - so as to guarantee the proper acclimatization of biomass to the new environment at the cost of minimum organic or hydraulic load shocks.

The reactors were fed with wastewater at increasing concentration of biological oxygen demand at $978 \mathrm{mg} \mathrm{L}^{-1}$ (start up), $2401 \mathrm{mg} \mathrm{L}^{-1}$ and $4545 \mathrm{mg} \mathrm{L}^{-1}$ preserving, however, the hydraulic retention time (HRT) of approximately 1.3 days. At each volumetric organic loading rate (OLR), the reactors were checked until a state of dynamic equilibrium was achieved, expressed by a balance between alkalinity consumption and the volatile acids production. Balanced conditions were maintained so as to make possible the collection of supporting material in order to define the biomass obtained. After completing this stage, organic loading was increased for all reactors, which went on to operate under new conditions till a new balance was achieved. From this point onwards, the fixed bed anaerobic reactors with ascending outflow were operated and monitored for a period of 119 days. These units worked under room temperature, with mean values of 16,17 and $19^{\circ} \mathrm{C}$ for every phase of the operation, respectively.

\section{Qualitative and quantitative assessment of the biofilm}

The biomass characterization conducted on each support material was obtained through electronic scanning microscopy. The main cell morphologies present in the film were also duly assessed. The samples were fixed with phosphate buffer (pH 6.8) containing 5\% glutaraldehyde for the period of $1 \mathrm{~h}$ and then rinsed 6 times at 10 min intervals with a buffer solution of phosphate $\left(0.1 \mathrm{~mol} \mathrm{~L}^{-1}\right)$ and distilled water, after which the dehydration was done with ethanol solutions in increasing concentrations of (30, 50, 70, 80, 95 and $100 \% \mathrm{v} / \mathrm{v})$. The samples, however, were rinsed three times with an ethanol solution $100 \%$ v/v. Each dehydration phase took $10 \mathrm{~min}$ to complete. The samples were dried up at $30{ }^{\circ} \mathrm{C}$ inside a $20 \mathrm{~nm}$ thick Critical Point Dryer Bal Tec CPD 030, whereas the particles were covered with a gold layer by means of a Sputter Coater Balzers SCU 010 and fixed upon aluminum supports (stubs) by means of an electron conductive pen. The material was examined with a LEO VP 1430 electronic scanning microscope, and the analyses were conducted at the Electronic Scanning Microscopy Nucleus of the Federal University of Viçosa.

To complete the experiment, two samples placed at three different spots in the reactors (the bottom, middle and top) were assessed in order to establish the quantification of the biofilm produced. The material was rinsed in distilled water so that the biomass stuck on to the surface of the support material could be removed (Show \& Tay, 1999). At the same time, the released solids were transferred to a $100 \mathrm{~mL}$ porcelain capsule for further examination to determine total solids (TS) and total volatile solids (TVS) through the gravimeter method (APHA, 2005).

\section{RESULTS AND DISCUSSION}

The concentration and quantity of adhered biomass for each support material used in the present study are shown in Table 3. Based on visual observations, it may be concluded that the biofilm formed on the surface of the support materials was blackish, viscous and of dense texture; the apparent thickness, however, varied in relation to the height of the reactor. Meanwhile, the greater thickness of the film was noticed to have occurred at the bottom of the reactor, whereas the biofilm of smallest thickness was noticed to occur on the upper layers of the reactor. As a rule, the biofilm glued to the polyurethane foam was seen to be far thicker and far more viscous than that found on other materials.

The presence of a larger quantity of microorganisms in the foam reactor was responsible for the higher efficiency values at the COD removal system, as verified with the use 
Table 3. Mean concentration and quantity of biofilm adhered to different materials used as support media at the final phase of the experiment

\begin{tabular}{ccccccccc}
\hline Support & \multicolumn{3}{c}{ Total Solids } & & \multicolumn{3}{c}{ Total Volatile Solids } \\
\cline { 2 - 4 } \cline { 6 - 8 } Materials & (a) & (b) & (c) & & (a) & (b) & (c) \\
Slag & 18.1 & 45.7 & 4322 & & 3.9 & 9.9 & 937 \\
Foam & 2255 & 37.0 & 4989 & & 1301 & 21.4 & 2880 \\
Crashed stone & 10.7 & 32.2 & 2895 & & 3.7 & 11.1 & 1002 \\
\hline
\end{tabular}

(a) solid mass per mass support material $\left(\mathrm{mg} \mathrm{g}^{-1}\right)$; (b) solid mass per utilizable volume of the reactor $\left(\mathrm{g} \mathrm{L}^{-1}\right)$; (c) total mass of solids in the reactor $(\mathrm{g})$

of this reactor during the three phases of the operation. Removal efficiencies of COD in relation to OLR as applied to each reactor are described in Figure 2. The biomass concentration maintained in the reactor in the form of TVS varied from 882 to $1627 \mathrm{mg} \mathrm{g}^{-1}$ of foam with an average value of $1301 \mathrm{mg} \mathrm{g}^{-1}$ : values similar to those obtained by Ribeiro et al. (2005), which varied from 1520 to $1690 \mathrm{mg} \mathrm{g}^{-1}$ of foam.

The quantity of bio-particles attached to the foam depends on the porosity index and the unevenness of the support material, therefore, the greater the area available for microbial colonization, the larger the capacity of biomass retention, and, consequently, the better will be the reactors' performance. According to Zaiat et al. (1997), this kind of support is capable of promoting ideal environmental conditions for syntrophic relations that involve a vast variety of species resulting in optimum utilization of primary and intermediary substrate.

The biofilm attached to the slag presented features comparable to those of crashed stone of smooth surface. Nevertheless, in spite of its roughness and grooves as detected in the slag, this was seen to be relatively fragile and easily removable. This aspect influenced enormously the quantity of biofilm attached to the blast furnace slag.

In spite of the greater removal of organic matter observed in the foam reactor, the other reactors have also presented satisfactory efficiencies, though they have presented smaller mass of microorganisms, quantified as TVS. Considering Table 3, the total mass of TVS in the reactor that contained

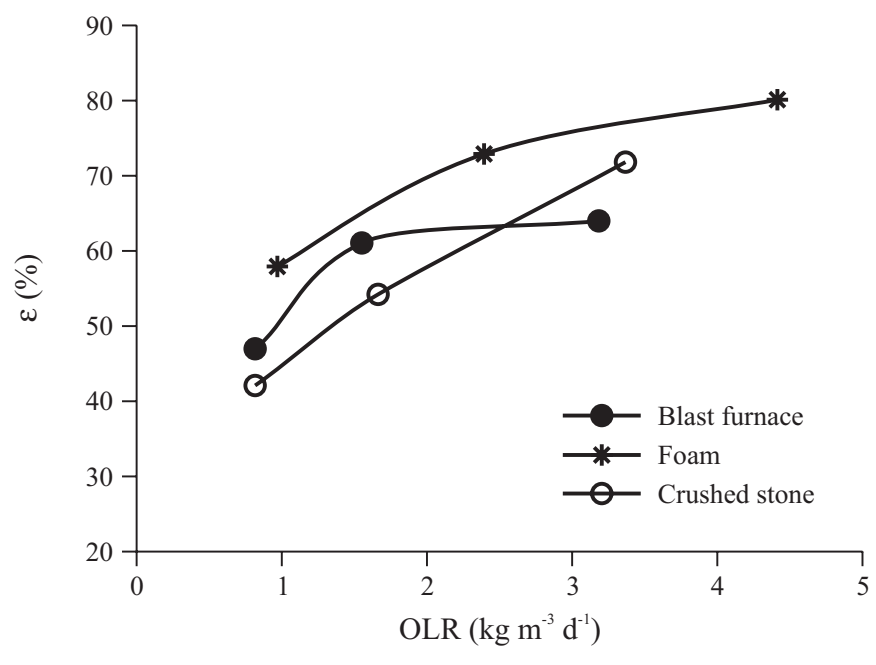

Figure 2. Efficiency in the removal of chemical oxygen demand $(\varepsilon)$ in relation to the volumetric organic loading rate oxygen applied to each reactor crashed stone was similar to that obtained in the reactor that contained blast furnace slag, being approximately 2.8 times smaller than that of the reactor that contained foam. However, the biggest advantage of using foam as a support material is certainly attributed to the reactor's constructive aspect, because smaller foam specific mass results in less costly treatment units.

Figures 3, 4 and 5 show the morphologic diversity of microorganisms present in immobilized biomass in the various support materials.

In all conditions, morphologies such as bacilli, cocci and filaments were found in the support materials of three reactors. However, the predominant morphology in all conditions studied was that including non-fluorescent bacilli with round contours, similar to those of the genus Methanosaeta sp. It was also verified that, besides these morphologies, the presence of cells similar to those of the genus Methanosarcina sp. in the reactor in which the slag was used as support material in the third phase of the system operation revealed a cubic disposition; a feature most commonly found in the characteristic cubic disposition of the cocci forming sarcina and also because of the typical fluorescence that results from the presence of coenzyme F420. The methanogenic archaea and the chemical properties of the blast furnace slag are factors that may be connected to the presence of Methanosaeta sp. in the support material. The presence of metallic ions, such as iron, in the blast furnace slag composition favors enormously the microbial metabolism, triggering the methanogenesis (Gourari \& Achkari-Begdouri, 1997). According to Buzzini et al. (2006), the bio-availability of trace metals may interfere with kinetic of growth, for in the absence of appropriate concentrations of these metals, Methanosaeta sp. emerges accounting for the ever growing frequency of this genus in the reactors. It must also be taken into account that environmental conditions of the reactors' operation do favor the developmental and persistence of Methanosaeta sp. in relation to the genus Methanosarcina sp.

Table 4 shows the frequency and the various microbial morphologies found in the biofilm attached to the support materials used in each reactor during the third phase of the system operation. The presence of curve bacilli was also observed, similar to sulphate reducing bacteria (SRB), indicating, therefore, the presence of sulphate in the medium.

Examining Figures 3, 4 and 5, it is verified that blast furnace slag, in spite of having presented poor performance in comparison to that of foam, gave rise to a larger variety of morphologies. One plausible justification for poor performance of this reactor has to do with the smaller amount of biomass attached to it in terms of TVS, as discussed previously. It may be concluded that, on account of the smaller amount of biomass in the slag, this configuration did not present favorable conditions to develop a stable highly concentrated microbial consortium; in other words, by utilizing the slag as support material one manages to obtain a large variety of microbial morphologies intended for anaerobic treatment of wastewater, but in smaller concentrations. 
A.

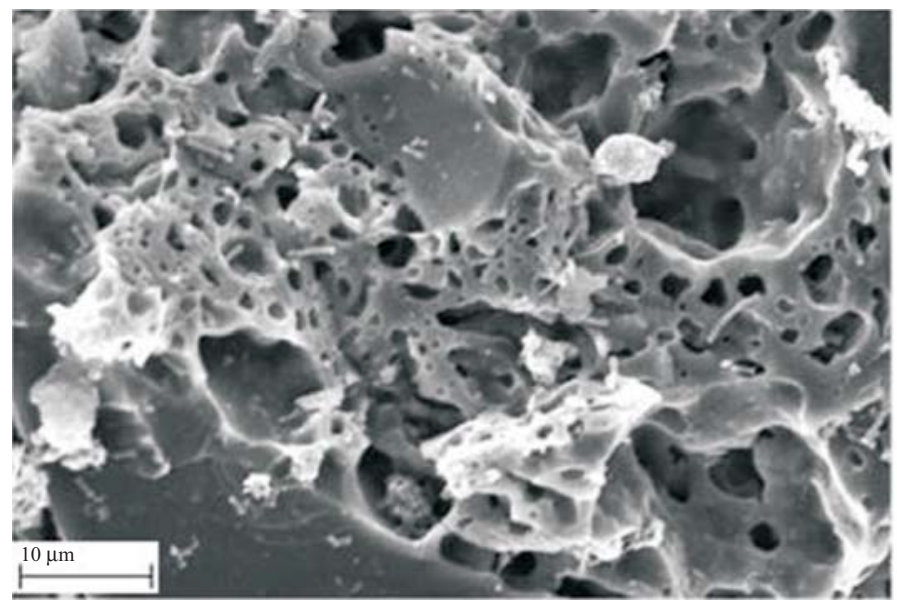

C.

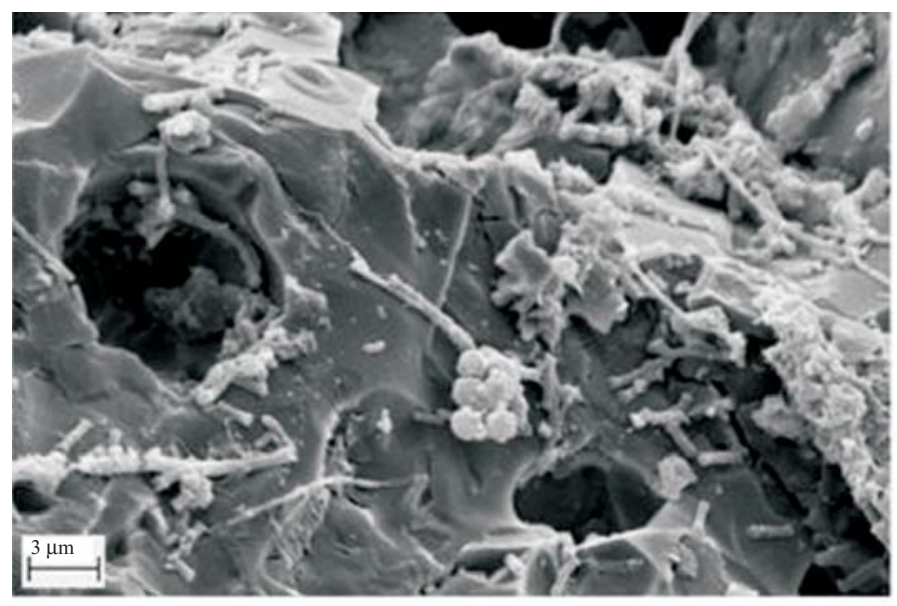

E.

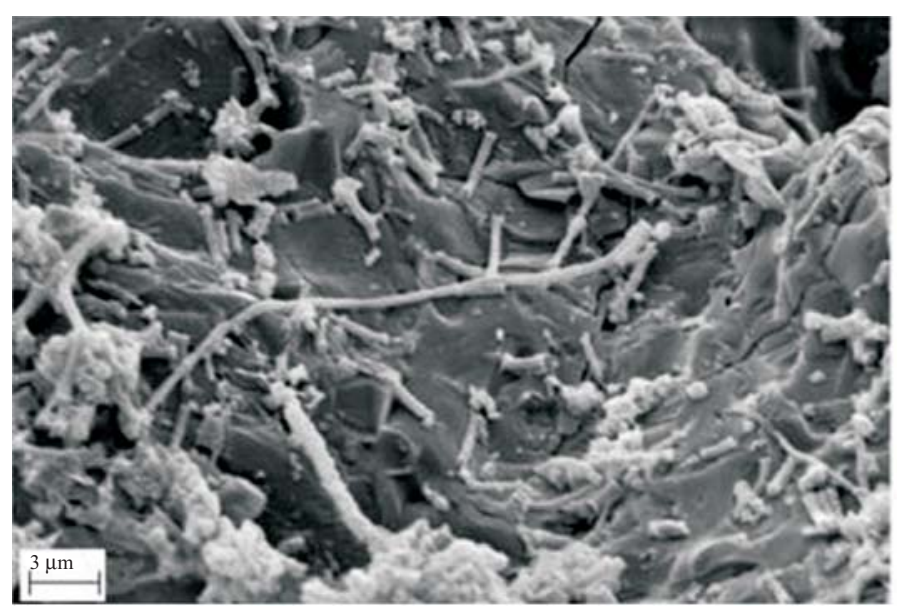

B.

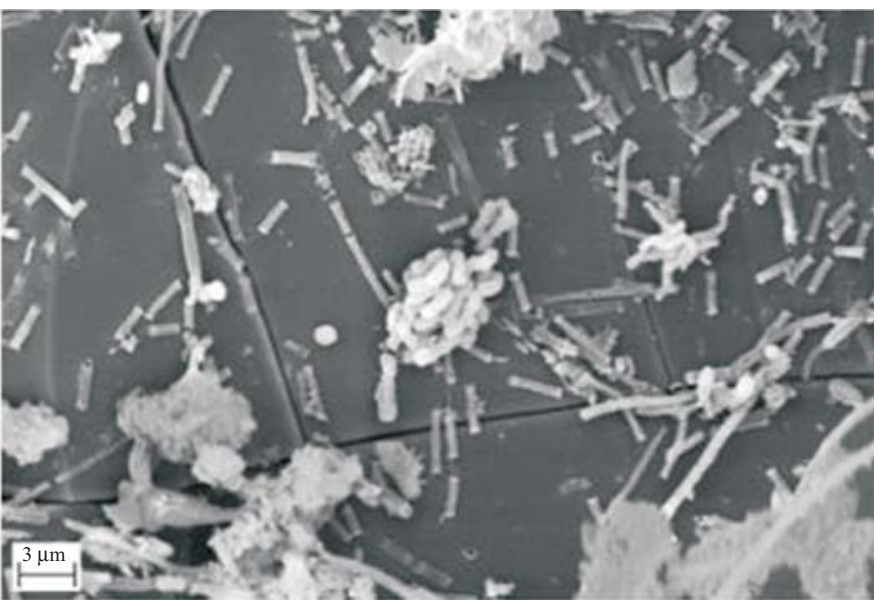

D.

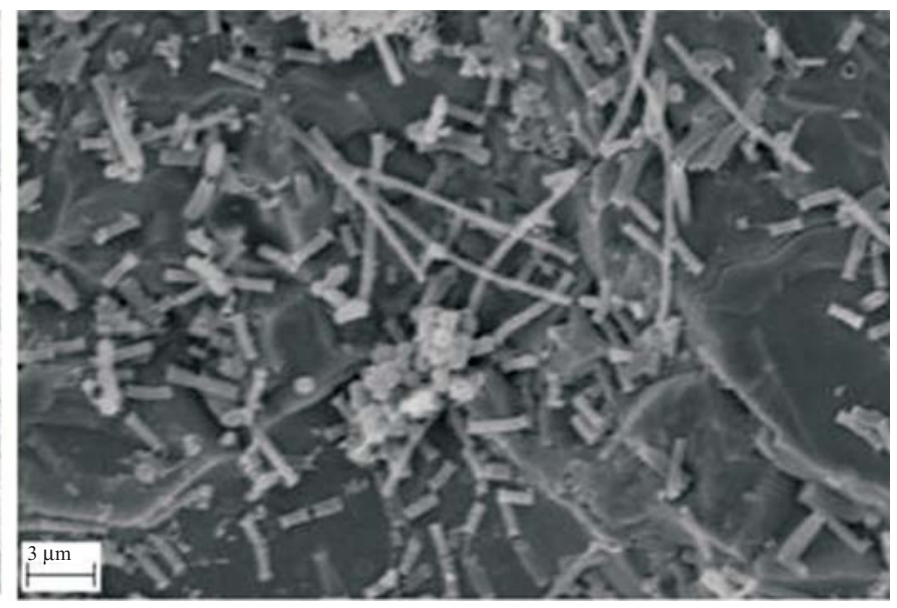

F.

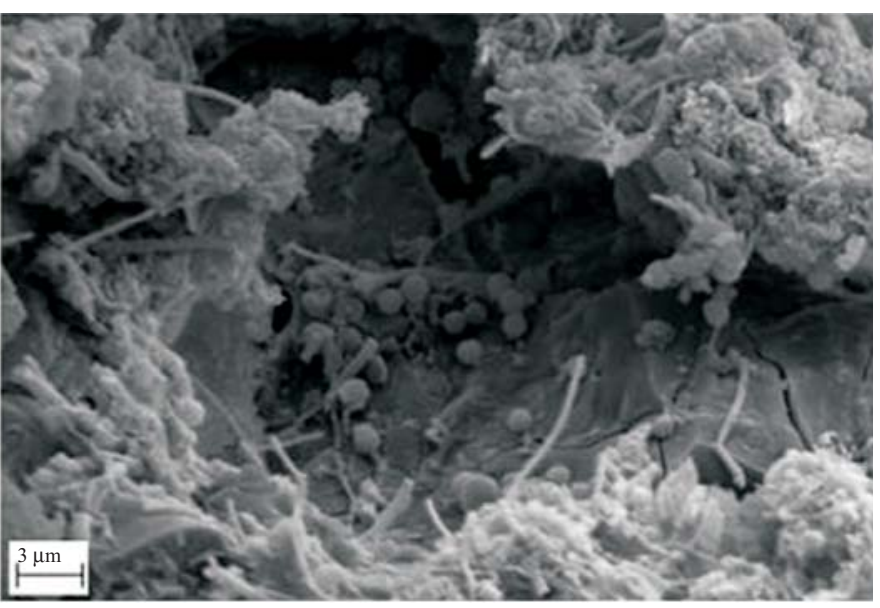

Figure 3. Morphological scanning observations of support material with blast furnace slag with an electron microscope for the treatment of wastewater from coffee grain processing. A: slag structure with the presence of rod; B: Methanosaeta; C: probably Methanosarcina and Methanosaeta; D: filaments Methanosaeta and Methanosarcina; E and F: probably Methanosarcina, filaments and Methanosaeta 
A.

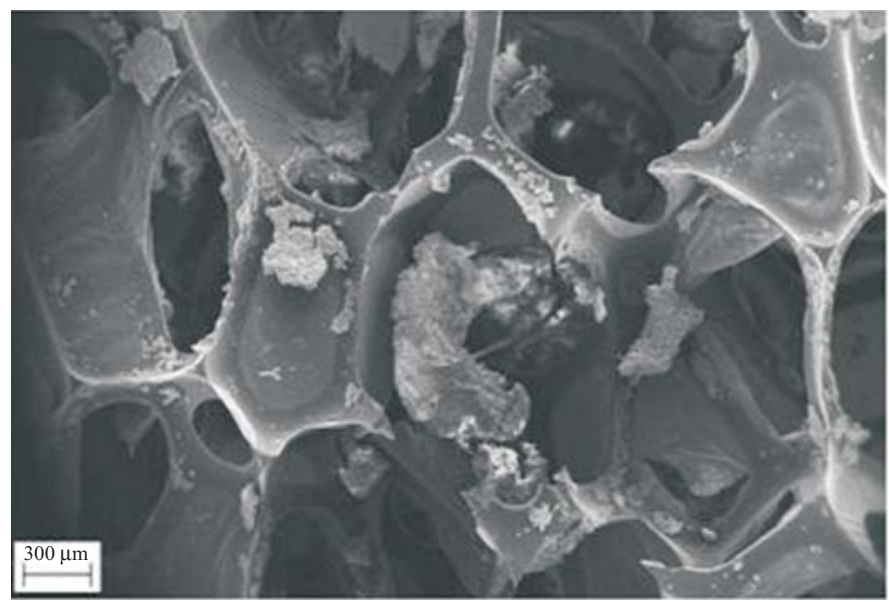

C.

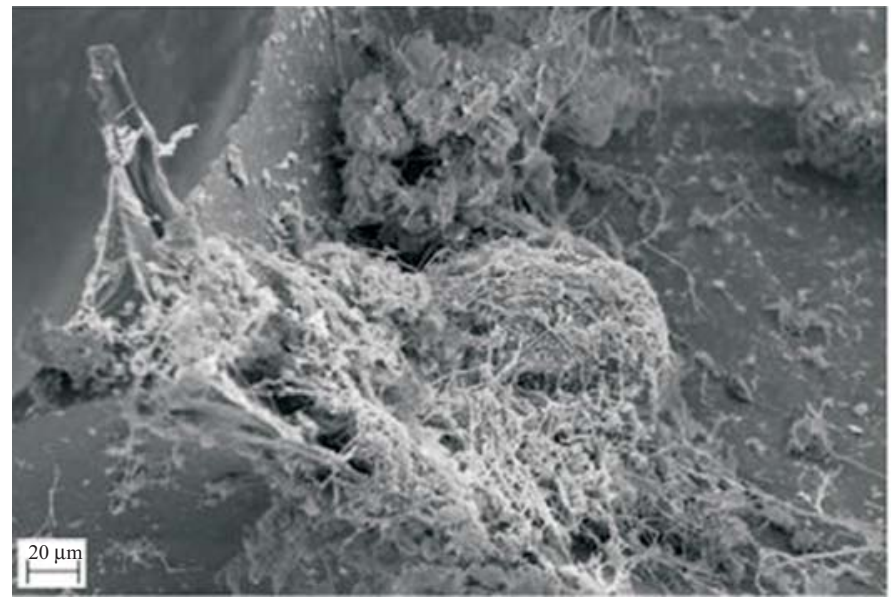

E.

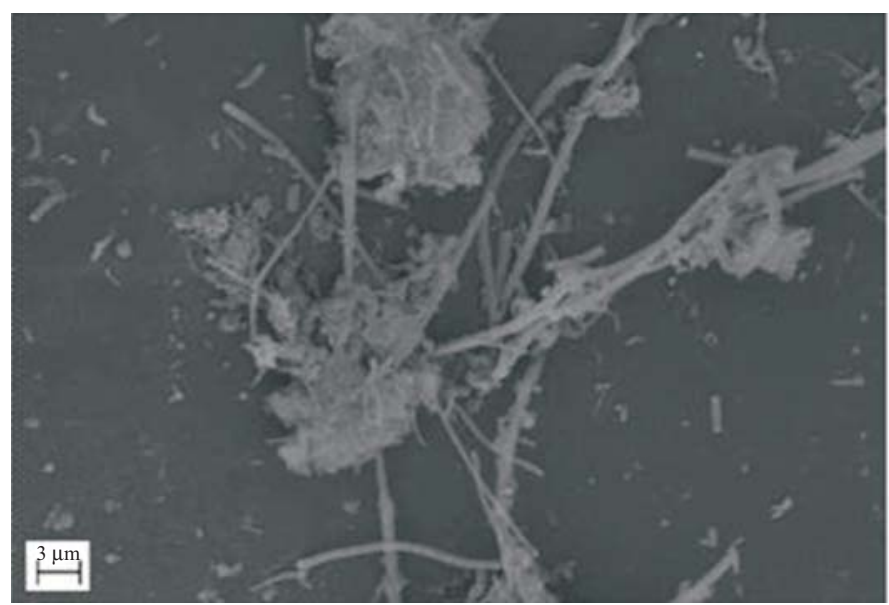

B.

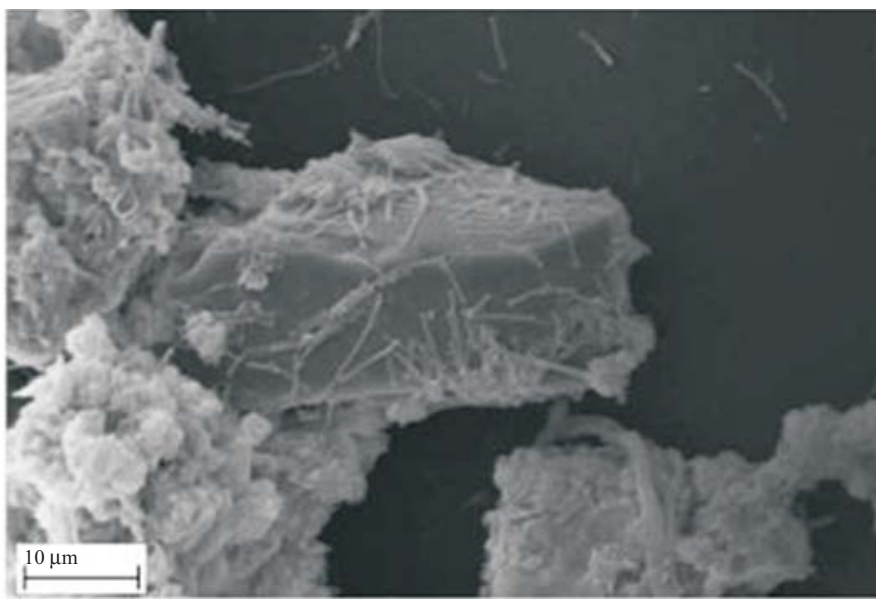

D.

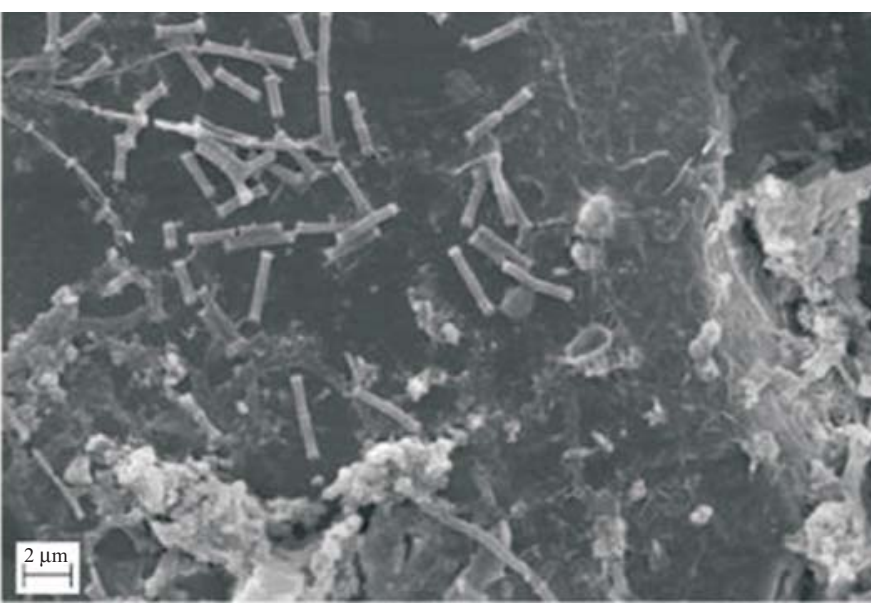

F.

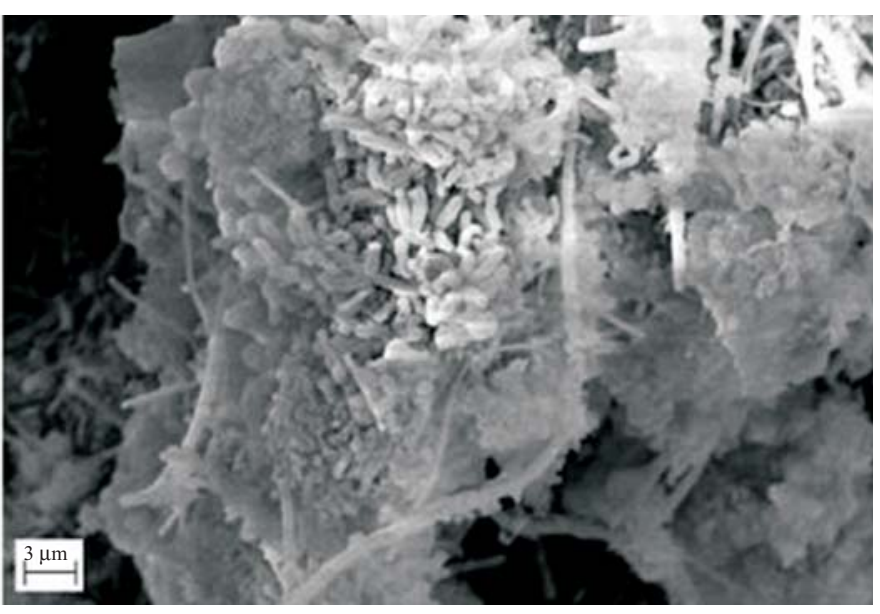

Figure 4. Morphological observations with scanning electron microscope of support material used in foam reactors for the treatment of wastewater from processing coffee grains. A: foam visualization; B and C: filaments; D: Methanosaeta; E: curved rod, cocci, Methanosaeta; F: filaments, curved rods and rod 
A.

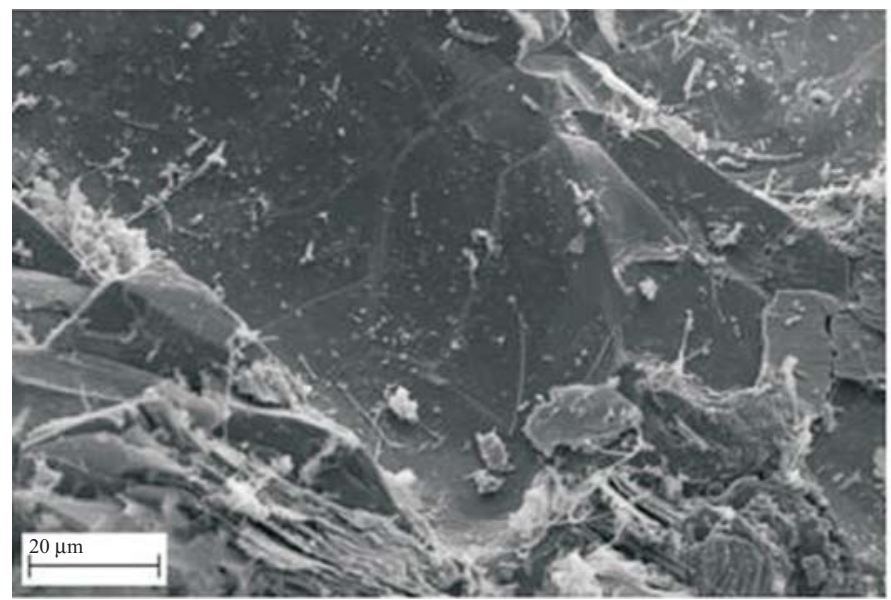

C.

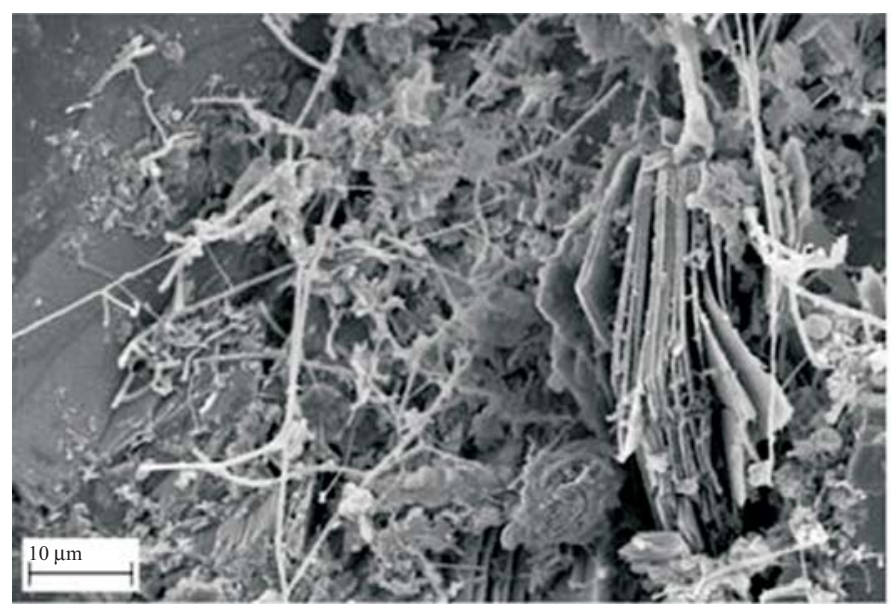

E.

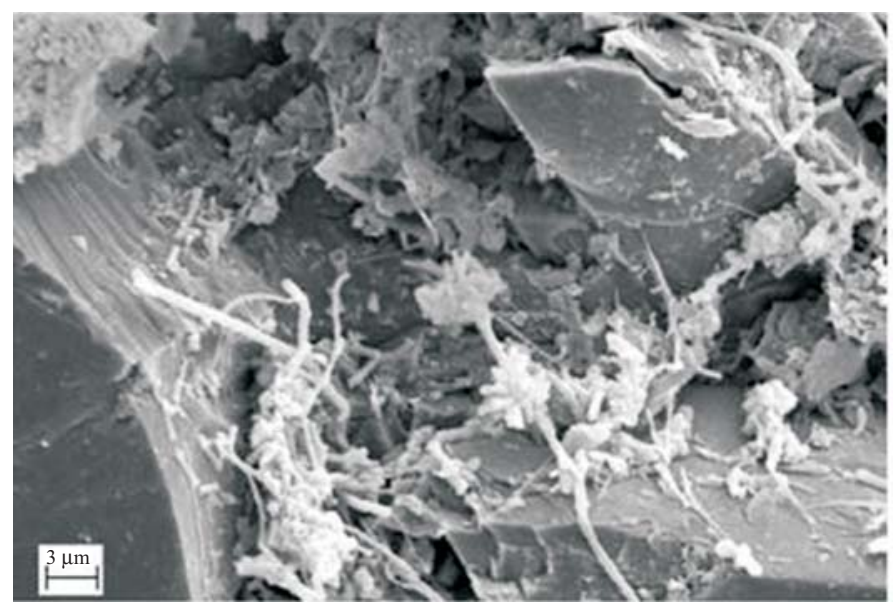

B.

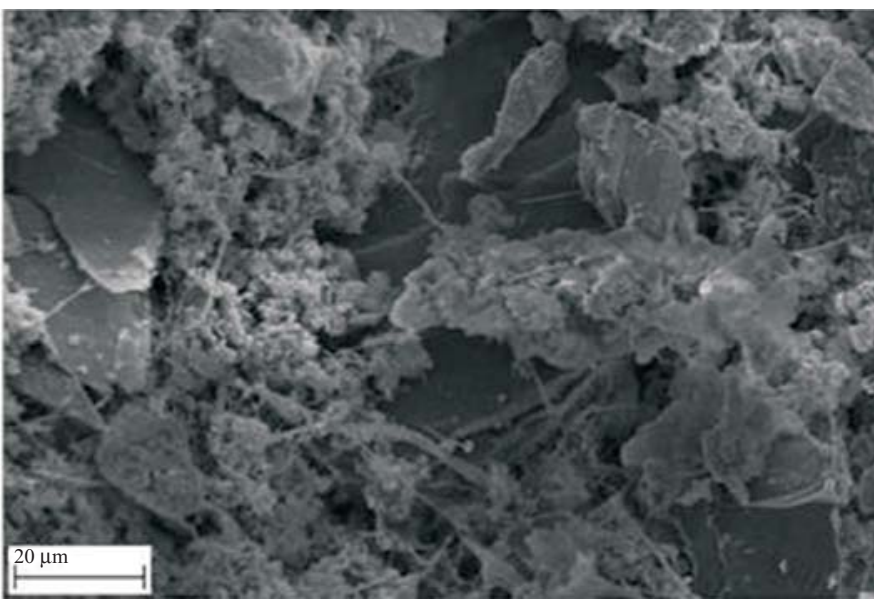

D.

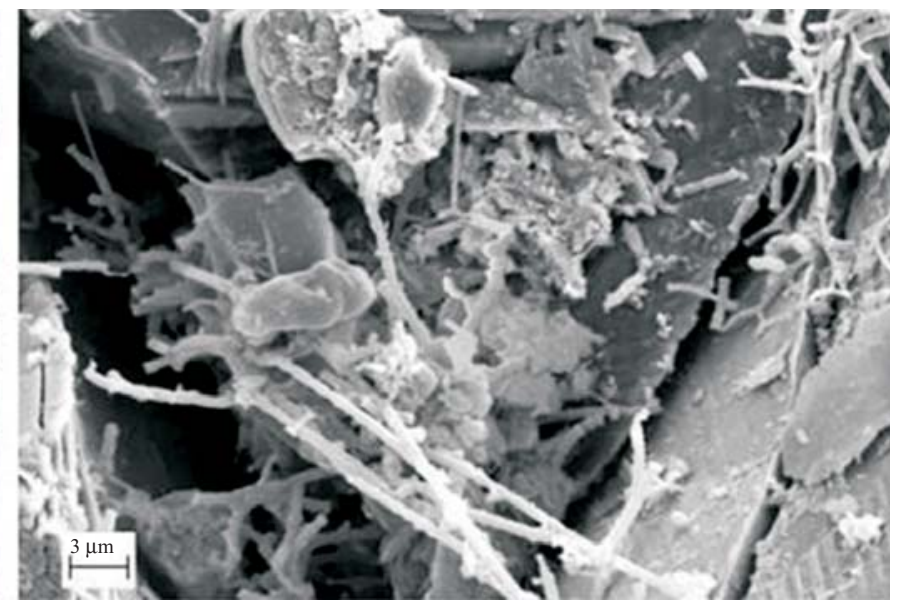

F.

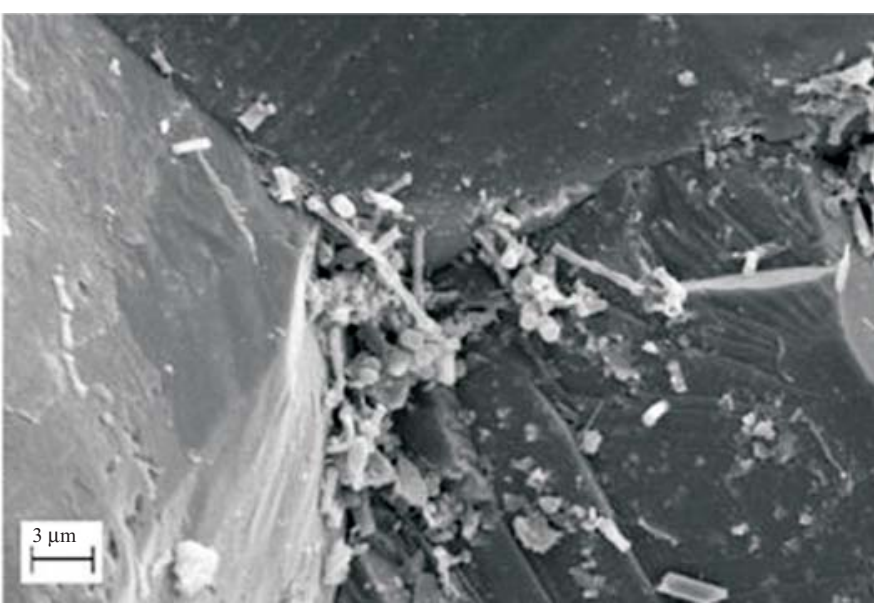

Figure 5. Morphological scanning observations by means of electron microscope of support material of the crashed stone reactor for the treatment of wastewater from coffee grains processing. A: rod, cocci and filaments; B: Methanosaeta; C and D: filaments and Methanosaeta; E: Curvad rods, rod and Methanosaeta; F: probably Methanosaeta and Methanosarcina 
Table 4. Morphological characterization of biomass present in anaerobic reactors treating wastewater during the third phase of the system operation

\begin{tabular}{|c|c|c|c|c|c|c|c|c|c|}
\hline \multirow{2}{*}{ Morphologies } & \multicolumn{3}{|c|}{ Blast furnace slag } & \multicolumn{3}{|c|}{ Polyurethane foam } & \multicolumn{3}{|c|}{ Crashed stone \# 2} \\
\hline & Base & Middle & Top & Base & Middle & Top & Base & Middle & Top \\
\hline Rods & + & ++ & ++ & + & + & + & +++ & ++ & ++ \\
\hline Curved rod & - & - & +++ & - & - & + & +++ & - & - \\
\hline Cocci & ++ & ++ & ++ & ++++ & - & + & ++ & +++ & +++ \\
\hline Filament & ++++ & ++++ & +++ & +++ & ++++ & +++ & ++++ & +++ & +++ \\
\hline Sarcine & - & ++ & - & - & - & ++ & - & - & + \\
\hline Methanosaeta sp. & +++ & ++ & +++ & ++ & +++ & ++++ & + & ++ & + \\
\hline Methanosarcina sp. & - & ++ & - & - & - & - & - & - & - \\
\hline
\end{tabular}

$(++++)$ predominant; $(+++)$ frequent; $(++)$ less frequent; $(+)$ rare; $(-)$ not observed

\section{CONCLUSIONS}

1. Blast furnace slag did not offer satisfactory conditions for the development of a stable microbial consortium with higher concentrations; however, it showed an enormous variety of microbial morphologies most appropriate for the anaerobic treatment, though at lower concentrations.

2. The microbial biofilm attached to the various support materials presented a variety of species with similar morphologies to those of rod, curved rod, cocci, filaments, Methanosaeta sp. and Methanosarcina sp.

3. The reactor filled with foam exhibited an average efficiency of $80 \%$ in removing COD, which can be attributed to its higher porosity index that favors better retention and fixation of biomass that, quantified in the form of chemical oxygen demand, was found to hold $1301 \mathrm{mg} \mathrm{g}^{-1}$ of material.

4. The polyurethane foam may be seen as an efficient alternative to support anaerobic fixed bed reactors.

\section{LITERATURE CITED}

APHA - American Public Health Association; AWWA - American Water Works Association; WEF - Water Environment Federation. Standard methods for examination of water and wastewater. 21.ed. Washington: APHA/AWWA/WEF, 2005. 1268p.

Buzzini, A. P.; Sakamoto, I. K.; Varesche, M. B.; Pires, E. C. Evaluation of the microbial diversity in an UASB reactor treating wastewater from an unbleached pulp plant. Process Biochemistry, v.41, p.168-176, 2006.

Chaiprasert, P.; Suvajittanont, W.; Suraraksac, B.; Tanticharoend, M.; Bhumiratana, S. Nylon fibers as supporting media in anaerobic hybrid reactors: it's effects on system's performance and microbial distribution. Water Research, v.37, p.4605-4612, 2003.

Colin, X.; Farinet, J. L.; Rojas, O.; Alazard, D. Anaerobic treatment of cassava starch extraction wastewater using a horizontal flow filter with bamboo as support. Bioresource Technology, v.98, p.1602-1607, 2007.

Gourari, S.; Achkari-Begdouri, A. Use of baked clay media as biomass supports for anaerobic filters. Applied Clay Science, v.12, p.365-375, 1997.

Kawasc, M.; Nomura, T.; Najima, T. Anaerobic fixed bed reactor with a porous ceramic carrier. Water Science. and Technology, v.21, n.4-5, p.77-86, 1989.
Lima, C. A. A.; Ribeiro, R.; Foresti, E.; Zaiat, M. Morphological study of biomass during the start-up period of a fixed-bed anaerobic reactor treating domestic sewage. Brazilian Archives of Biology and Technology, v.48, n.5, p.841-849, 2005.

Omil, F.; Garrido, J. M.; Arrojo, B.; Méndez, R. Anaerobic filter reactor performance for the treatment of complex dairy wastewater at industrial scale. Water Research, v.37, p.4099-4108, 2003.

Ortega, F. S.; Rocha, K. M.; Zaiat, M.; Pandolfelli, V. C. Aplicação de espumas cerâmicas produzidas via "gelcasting” em biorreator para tratamento anaeróbio de águas residuárias. Cerâmica, v.47, n.304, p.199-203, 2001.

Picanço, A. P.; Vallero, M. V. G.; Gianotti, E. P.; Zaiat, M.; Blundi, C. E. Influence of porosity and composition of supports on the methanogenic biofilm characteristics developed in a fixed bed anaerobic reactor. Water Science and Technology, v.44, n.4, p.197-204, 2001.

Ribeiro, R.; Varesche, M. B. A.; Foresti, E.; Zaiat, M. Influence of the carbon source on the anaerobic biomass adhesion on polyurethane foam matrices. Journal of Environmental Management, v.74, p.187-194, 2005.

Ruiz, I.; Veiga, M. C.; Santiago, P.; Blázquez, R. Treatment of slaughterhouse wastewater in a UASB reactor and an anaerobic filter. Bioresource Technology, v.60, p.251-258, 1997.

Show, K. Y.; Tay, J. H. Influence of support media on biomass growth and retention in anaerobic filters. Water Research, v.33, n.6, p.1471-1481, 1999.

Torres, P.; Rodríguez, J. A.; Uribe, I. E. Tratamiento de aguas residuales del proceso de extracción de almidón de yuca en filtro anaerobio: Influencia del medio soporte. Scientia et Technica, v.23, p.75-80, 2003.

von Sperling, M. Princípios básicos do tratamento de esgotos: Princípios do tratamento biológico de águas residuárias. Belo Horizonte: DESA/UFMG, 1996. 211p.

Zaiat, M.; Cabral, A. K. A.; Foresti, E. Horizontal-flow anaerobic immobilized sludge reactor for wastewater treatment: Conception and performance evaluation. Revista Brasileira de Engenharia, v.11, p.33-42, 1994.

Zaiat, M.; Vieira, L. G. T.; Foresti, E. Spatial and temporal variations of monitoring performance parameters in horizontal-flow anaerobic immobilized sludge (HAIS) reactor treating synthetic substrate. Water Research, v.31, n.7, p.1760-1766, 1997.

Zellner, G.; Vogel, P.; Kneifel, H.; Winter, J. Anaerobic digestion of whey and permeate with suspended and immobilized complex and defined consortia. Applied Microbiology and Biotechnology, v.27, p.306-314, 1987. 